\title{
Financing and Management of Higher Education: Evidence from Jordan
}

\author{
Emad El-Sheikh \\ Associate professor, Accounting Department, Applied Science University, Jordan \\ E-mail: emad_sh@asu.edu.jo \\ Osama Mah'd \\ Assistant professor, Accounting Department, Applied Science University, Jordan \\ E-mail: o_mansour@asu.edu.jo \\ Mahmoud Nassar \\ Assistant professor, Accounting Department, Applied Science University, Jordan \\ E-mail: aman_spic@yahoo.com \\ Husam Aldeen Al-Khadash \\ Associate Professor, Accounting Departement, Hashemite University, Jordan \\ E-mail: husam@joconsultancy.com
}

Received: February 15, 2012

Accepted: March 8, 2012

Published: May 1, 2012

doi:10.5539/ibr.v5n5p71

URL: http://dx.doi.org/10.5539/ibr.v5n5p71

The authors are grateful to the Applied Science Private University, Amman, Jordan, for the full financial support granted to this research project.

\begin{abstract}
This research provides a better understanding of the way for financing and management of higher education in Jordan. The study aims at describing the finance and management methods in Jordanian HE. The private universities in the world were also described in terms of their financing and management method. The Research uses archival documents, observations, and reports in order to accomplish the study objective. The findings emphasize that Jordanian HE is one of the most developed higher educational systems in the Middle East countries. There is much competition in the private HE, this motivates to research the best ways of management and financing for this sector. Worldwide, there is a trend towards private HE. While, world wide private universities depend on tution fees, they receive government subsidiaries. In Jordan, private universities are mainly financed by student tuition fees, and they do not receive any subsidies from the government. Therefore a proper budgetary system might facilitate the need for effective management of university resources and decision-making.
\end{abstract}

Keywords: Jordanian private universities, Finance of HE, Management of HE

\section{Introduction}

The management and finance of higher education (HE) is not isolated from social, geographical, or other issues (Mah'd, 2010). This research aims at providing a background on higher education finance and management. It demonstrates on the private universities in Jordan and provide overview on the private HE in the world.

This research is designed into two main parts in order to explore and highlight Jordanian higher education context and compare it with HE world wide. The first part illustrates and explains the Jordanian higher education system in regard to the quality assurance, organisation, governance, legislation, finance and management of public and private universities. It also discusses HE expansion in Jordan. The second part describes higher education around the world, with a focus on HE expansion and the reform, finance, and management of universities as well as privatization within HE. 
The Jordanian demographic structure is unique in that the population is highly educated, and it has the highest literacy rates in the region (See Hutaibat, 2005). In addition to high education rates, Jordan's population is relatively young (more than 50\% of Jordanians are under 18 and more than 70\% are under 33) (Hutaibat, 2005; Zeitun, 2006; and Aladwan, 2007). According to the Ministry of Education (2008), the population is expected to reach 11 million over the next thirty years. This structure makes it difficult for the economy to generate jobs and sustain living standards.

Jordan is a developing country with very limited resources and inadequate supplies of water and other natural resources. Hutaibat (2005) describes Jordan's economy as one which is small, open, and service-oriented. The nation is characterised by its geographical position, political stability, highly educated workforce, and competitive labour force.

\section{Privatization in Jordan}

Privatization considers a key issue and important aspect for economic development, as it plays a vital role in firm health and corporate failure (Zeitun, 2006). In the early nineties, the Jordanian government adopted privatization in an economic revolution. Privatization was as a result of a range of studies on public sector projects and recommendations by the World Bank (Hutaibat, 2005). A variety of reasons functioned as incentives for the Jordanian government to adopt a privatisation policy. These reasons include: globalisation, the rise of competition, accountability, increasing customer demands, communication, and the information revolution (Mah'd et al., 2011).

Mah'd (2010) points that Jordan started to adopt privatisation in several sectors such as communications, transportations, electricity, water supply, education, mining and energy refinement. This is a trend followed by many countries. This transfer from public to private sector introduces competition into these markets (Johnstone, 1998). It is argued that private firms clearly pursue profit more than public firms would, and management in these firms is more responsible: they look for good quality administration and performance and they control resource allocation. In this business environment, the private Jordanian Universities Act was born in 1989 (Temporary Law 19), and it opened the door for investors to establish private universities to improve the private education sector.

It is notable that the Jordanian privatisation process has accomplished remarkable progress since 1990. Participations in public shareholding companies declined from $15 \%$ to less than $6 \%$ and most of this $6 \%$ are firms in mining industries (see Zeitun, 2006). Many other examples, such as tourism companies, cement factories, large banks and the largest communication company (Note 1) are evidence of this movement to privatisation. Jordan's privatisation program is one of the most successful programmes in the region (Aladwan, 2007; Mah'd, 2010; Hindi, 2008).

Mah'd, 2010 found that higher education in most developing nations have been moving tuition costs from the general populace (government taxes) to students or their families (Note 2). In other words, governments are shifting the burden of higher educational costs from the taxpayer to students or parents of students and to philanthropists (Mah'd, 2010). This movement is well-grounded (Trebilcock \& Iacobucci, 2003) and is notable in Jordan.

All over the world, privatisation has been expanded to include the HE sector, where many new regulations have been implemented to support privatisation. Over the past two decades, Jordan has been interested in the privatisation of higher education on a national scale, since it has been argued that this will improve competence, satisfy parents' preferences, make universities more accountable, and reduce government expenditure (Mah'd et al., 2011). This conception has been developed in order to enhance higher education development insofar as there is pressure to expand student numbers or to reduce costs, enhance research, and apply the result of such research more effectively. The attitude of higher education has changed dramatically towards privatisation in recent years and will undoubtedly continue to change in the years ahead.

\section{Education}

"We have made it a priority to address the challenges of meeting international standards in technology, education, and production in order to grasp the full benefits of globalization."

His Majesty King Abdullah II, 2005

Educating children is one of the first priorities amongst Jordanians, and the majority of the population is interested in education (Mah'd, 2010). According to various prior studies, Jordan has the best-educated and qualified population in the entire Islamic world (Wilson, 1987) included Middle East and North Africa (Hindi, 2008; and Mah'd et al., 2011). The Ministry of Education (MoE) is in charge of organising and supervising all aspects of education including determining the content of the curriculum, deciding on textbooks recruiting teachers, and organising examinations throughout the country. According to the MoE (2008), its aim is to create and organise a system of education built on human resources and dedicated to high standards. 
Educational process in Jordan has dramatically expanded during the last two decades (Mah'd, 2010). Khasawneh et al. (2008) figures that the educational attainment average of the adult population was ten years in 2005, which compares well with such countries as Greece and Italy, and is indeed higher than comparable figures in Mexico and Portugal. The secondary graduation rate of $70 \%$ in 2003 is higher than this same rate in Spain, Slovak Republic, Turkey, or Mexico (Khasawneh et al., 2008). Compared to other Arab countries and developing countries, Jordan has a higher proportion of students, both boys and girls, attending its schools (Alshurfat, 2003; Mah'd, 2010).

Education is free in all stages of education (not higher education) for all Jordanian students; it is mainly financed by the general government budget and includes textbooks free of charge for most of the educational process). The state provides books at a nominal price for students in secondary education. However, despite Jordan having one of the best educational systems in the region (see Hindi, 2008; Khasawneh et al., 2008; Mah'd, 2010; Wilson, 1987), the Jordanian education system is still struggling to ease the challenge of a burgeoning youthful population. This growing young population demands continuous expansion of the educational system, including improved quality of available teachers, books, and facilities.

\section{Jordanian Higher Education}

Higher education based on a significant role in qualifying and educating the work force and providing development in all regards such as content, programmes, and other teaching and learning styles). This has encouraged Jordan to give higher education particular consideration and development plans (see MoE, 2008). Khasawneh et al. (2008) state that the cultural tradition of attaching more prestige to academic qualifications than to vocational training causes high demand amongst Jordanians for university level education. This, in turn, has caused a sharp increase in the university graduation rate. Jordan has an exceptional higher education system, which offers options not always available in developing countries (see World Bank, 1996; Mah'd \& Roger, 2009; Mah'd, 2010). Primarily, these options are different in the ownership style (public and private), and patterns of educational system (universities and colleges). The credit-hour system, which entitles students to select courses according to a study plan, has been implemented at Jordanian universities and colleges.

In 1989, Jordan has started a HE reform when the government allowed private institutions or individuals to establish HEIs. Through various laws, such as the Law no. 43 for 2001 (which has subsequently been amended by another law in 2005), MoHE and Scientific Research in Jordan have attempted to achieve the following: the improvement of management of the HE sector, the enhancement of HE quality, the improvement of scientific research quality and the provision of developed databases in accordance with international practices. (Note 3)

\section{Research Methodology}

Prior research shows that, whilst several research have been carried out regarding financing and management of HEIs, little research has been conducted regarding private universities in developing countries particularly in Jordan. Therefore, this study aims to shed light on the ways of financing and management of these universities. The study uses documentary secondary data collection method. This includes written documents from the ministry of higher education in Jordan, Jordanian universities, books and journals.

\section{Research Objectives}

This research aims at describing the ways of financing and management of HE in Jordan. The study also aims to explore the ways of financing and management of HE worldwide.

\section{Research Question}

- What are the financing and management methods used in private HE in Jordan?

\section{Research Sample}

The Jordanian private HE sector (and particularly the private university sector) has been chosen as ground for this research. Private universities are supervised and financed by non-governmental institutions or individuals. According to Ministry of Higher education there are 19 private universities in Jordan. Selecting a single university where there is good access to funding and management information could enable in-depth data, but generalizability will not be addressed. Therefore, research benefits may be considered less significant. The selection of a single segment (HE), assuming a relatively small variance in population characteristics, was also considered in order to minimise the confusing effect of the unrelated variables, where internal validity might be under threat (Pollanen, 1996).

Data is collected for this research using documentary secondary data collection methods in order to make it easy to establish a broad background and to build up data about these universities (Saunders et al., 2009). The study 
concentrates on private universities but sometimes uses puplic universities in order to provide a solid background for the research

\section{Research Results}

Mah'd (2010) explained how the Jordanian higher education has developed steadily over the past two decades in regards to content, programmes, and methods of teaching and learning. Moreover he explained also how that affects both the quality and quantity of education. Jordan has achieved noticeable progress and expansion in higher education despite limited natural and financial resources. The number of students attending Jordanian universities increased from 28,439 in 1986-1987 to 103,092 in 1998-1999, and 236,920 in 2007-2008 (Department of Statistics, 1987; MoHE, 2008). This expansion was mainly financed by private sources (Figure 1). Several studies which present these figures claim that Jordan's investment in human capital (education at all levels) is a cost effective investment (Khasawneh et al., 2008).

Since the 1960s, Jordan has developed a relatively diverse system of HE. This diversity includes 27 universities (Note 4), ten of which are public universities. Although all public (government) institutions of HE receive a small proportion of support, they must also fund themselves through various means mainly this occurs through tuition fees. However, although public universities charge relatively lower tuition fees than private universities charge, public tuition fees have increased sharply in the past few years. Consequently, many parents are unable to afford the increasing fees (Jansen, 2006).

\section{Insert Figure 1 Here}

\section{The Jordanian Higher Education System}

Three cycles comprise the general framework of higher education at Jordanian universities. The first cycle (the Bachelor's Degree) usually lasts four years, but it is five years for Engineering, Pharmacy, and Dentistry and six years for Medicine. The second cycle (the Master's Degree) usually takes two to three years. It requires the first degree to have been received with a minimum assessment of good. The third degree $(\mathrm{PhD})$ lasts three to four years and requires both a first degree and a second degree, with a minimum assessment of very good for the second degree. Although, the teaching language at all universities is Arabic, English is used in some faculties, such as those of Medicine, Dentistry, Pharmacy, Engineering and recently in Business Administration. Jordanian universities operate under specific Jordanian laws.

\section{Quality Assurance (Accreditation)}

The MoHE is in charge of development in higher education in terms of quality and excellence. Consequently, it has developed a strategy for higher education and scientific research. This strategy includes the admission policies of Jordanian universities, as well as university legislation, developing human resources, university management, and quality assurance. The accreditation policy is the core component to implementing this strategy (Mah'd, 2010). Two main objectives which always lead the accreditation process are quality and excellence. In order to move towards progress in quality and excellence, private universities have been encouraged by laws, guidelines, and benchmarks. The Jordanian higher education environment attracts investors to set up private universities, but the ministry does ask for very high quality and standards. Of the 24 applications received in 2004, only four were given permission to proceed.

The MoHE is concerned with two kinds of accreditation (Mah'd \& Roger, 2009). The first type is called general accreditation, is related to the whole university, and is based on university structure, lands, buildings, and services. The aim of this accreditation is to provide the students a friendly study and research campus. The MoHE decides the number of students according to general accreditation facilities with a maximum of 8000 student, depending on four main criteria. These criteria are the student: staff ratio in every faculty, the overall availability and size of classrooms and labs, the library, and all other university facilities. The second type of accreditation involves the departmental or the programmes accreditation; this is known as special accreditation, based on the level of education provided to every respective programme. This type of accreditation involves the ratio of staff to students and the minimum number of degrees required in every academic department. The aim of this type of accreditation is to guarantee an advanced level of education and research in the academic departments.

These conditions and criteria have been implemented in order to maintain a good name for private universities outside the Kingdom. Jordan's good educational reputation encourages a high percentage of foreign students to study at the nation's universities. For instance, in Applied Science University (ASU) -one of the biggest and oldest of private Jordanian universities- more than $45 \%$ of the total students are foreign (Mah'd, 2010). Nevertheless, although private universities have a good reputation outside the Kingdom, within the Jordanian community private universities are perceived as providing a low quality of education. There are two main reasons for this view. The 
first is because strong competition for limited places (due to low tuition fees and high quality) enables public universities to attract the students who have the highest mark averages. The second is the view that private universities are profit seekers which tend to set lower entry standards and give high grades to students in order to increase their intakes. Jansen (2006) indicates that the rapid increase in state university fees and the acceptance of the Parallel Programme, wherein students with lower grades but a willingness to pay high fees can be accepted to study in state universities, have diminished the two perceived advantages of low price and high quality.

\section{Governance and Legislation}

In order to meet the need for regulation, planning and controlling HE policies, the Jordanian Council of Higher Education was established in 1982. The programmes offered by both private and public institutions have been overseen by the Higher Education Council, the Accreditation Commission, and the Higher Committee for Scientific Research. The MoHE and Scientific Research was established in 1985 to establish policies and practices, to collect relevant statistics, and to approve the establishment of new institutions (MoHE, 2008). It evaluates private and public institutions in terms of their programmes' effectiveness in implementing higher education's vision, tasks, and objectives. The Ministry was established to apply the mission of the government's educational strategies. It is headed by a senior minister, who is largely concerned with implementing decisions made by the Higher Education Council, which is also chaired by the Minister.

According to Laws No. 43 (2001), and No. 20 (2009) in regard to public universities, each university enjoys its autonomy and independence both financially and administratively. The law defines the public university as an academic institution which operates to achieve the objectives of higher education and scientific research. Each university has a council of trustees that plans strategies, approves policies and plans (such as the overall budget), and seeks external financial resources for the university. In addition to the trustees' council, every public university must have a university council and council of deans. In terms of financial matters, every university must have an independent budget prepared by the president, approved by the trustees' council, and signed by the MoHE.

Law No. 43 (2001), called the private universities law, organises university activities and structure. Investors can apply to the Higher Education Council in the MoHE to establish a university. Each university enjoys financial and administrative autonomy, which enables it to own property and operates legally in the community. The private university has been defined by law as an academic institution which operates to achieve the aims and objectives of higher education and scientific research. Thereby, the university must have a private, administrative, and academic organisational structure which is headed by the president and is fully independent of the owners (Law No. 20, 2009).

The allocation of funds between public universities, the enrolments to both public and private universities, the annual entry standards, accreditation of private universities and their programmes (both initially and annually) and the senior appointments in public universities, as well as the presidents of private universities, are decided by the Higher Education Council. This council is the most authoritative and influential governance body in Jordanian higher education. In 2001, HE Act No. 43 was authorized (and annulled the previous Act).

\section{Financing Public Higher Education}

HE in Jordan began in 1962. At the time there were around 200,000 school students with a soaring need for educated teachers as one of the main governmental priorities. This was the primary reason for establishing the first Jordanian university: The University of Jordan. The increasing number of secondary graduations led to an increased demand for $\mathrm{HE}$ as well as a need for a greater number of universities.

In respect to financing public universities, Jordan has, according to Sanyal (2006), an innovative method, which has been implemented by the Ministry of Finance, to collect a university tax on each single sale by or through individuals or corporations. The total revenue from this tax is redistributed to public universities by the MoHE on the basis of student numbers, total budget, new programmes, and development needs. This is not the only subsidy provided by the government; additional funds can be provided to the universities based on recommendation by the MoHE. These two methods, taxes and subsidies, have played an important role in financing public universities in their infancy.

The second largest source of revenue is tuition fees and other lump-sum fees. Another source of funding is the private sector, which plays a role in this process, since individuals, as well as local, regional, or international institutions, provide donations to the universities. The fourth source is asset investments in stocks or real estate where the returns usually finance generation projects. Loans from the government, or from banks, guaranteed by the government, can occur when there is a budget deficit.

In the past, public universities were mainly dependent on the government, while tuition fees constituted the second largest funding source. This has been changed as the universities created a further means of education and funding 
the parallel system. The parallel system is an alternative system for students who seek HE in public universities but failed to achieve the necessary grades to qualify for university entrance. This scheme allows such students to register in public universities, but they are required to pay a level of tuition fees similar to those who are studying in private universities. These high tuition fees have reduced the deficit in the universities' budget. The parallel system was not the only income generation choice available to public universities; they have also increased the normal tuition fees at least three times since 2000. Although these policies may reduce the budget deficit, Jordanians must still pay a relatively high amount for their studies. The noticeable increase in tuition fees makes it more difficult for many families to afford tertiary education for their children.

\section{Private Universities}

While Jordan was struggling to meet the rising demand for HE, the nation took the initiative of granting licenses to commercial companies to establish private universities at an earlier stage than did neighboring countries (Issa, 2000; Mah'd \& Roger, 2009). Before the existence of private universities in Jordan, the number of general secondary school graduates in Jordan exceeded the capacity of public universities, even though only a small proportion of secondary students qualified to continue their education at the university level. Moreover, Jordan's financial resources are very limited, so the number of existing public universities simply cannot expand as quickly as private universities do (Issa, 2000). Each year, over 50,000 students qualify for university admission, while the public universities can absorb only around half of this number (Note 5). Therefore, the surplus of students was going out of the country to study. Before 1990, around half of all Jordanian students were studying abroad each year, which affected the economy (Burke \& Al-Waked, 1997). This situation caused both social and financial problems to the Kingdom (see Issa, 2000). As a partial response, the Jordanian government established a new system of universities in 1989 which does not rely on government subsidies. The new system ended the flow of hard currency out of the country, created new jobs, and provided competition to the public sector.

According to Issa (2000), Jordan leads the Middle Eastern countries in running for-profit universities: the seventeen private Jordanian universities (unlike private universities elsewhere (Note 6)) run on a commercial basis. This gives rise to serious questions about the impact of profit incentive on private universities. It has been argued that such private universities do not protect the quality of education. Indeed, the public universities are older, and they are considered more prestigious than their private counterparts. In the eye of the public, public universities perform much better than private universities do. However, figures taken from the MoHE report that the cost per student in private universities is higher than comparable costs in public universities, thus providing some evidence that these institutions spend more to maintain good educational quality and services. Burke and Al-Waked (1997) argue that no evidence exists to prove that public universities are providing a better education than private universities. Moreover, the MoHE organises every term exam for all graduates from all Jordanian universities (this is called the out exam, or Alkafaa test) in order to compare and evaluate the performance of all Jordanian universities. The test has found no significant differences between graduates from private and public universities (MoHE, 2008).

Since the establishment of private universities in Jordan, questions have been introduced regarding how these emerging universities will be able to tackle the challenges of growing numbers of students seeking HE. Will they be able to provide an educational level equivalent to the level provided by public universities? Can they establish new forms of accountability and innovate new techniques? Over the last two decades, PJUs have proved their ability not only to absorb the surplus of Jordanian students, but also to attract foreign students (Note 7). PJUs have grown quickly, providing successful examples of innovations from which public universities replicate their decisions. Public universities even imitate some of the private universities' techniques and strategies. The money raised through the popular parallel programmes, the increasing price of the educational hour, and private programmes for non-university students have all played vital roles in funding public universities in the last decade. Despite increasing prices and government support provided to public universities, these universities still face a budget deficit every year. This may prove that PJUs managements, which are all for profit, have shown less bureaucracy than their public counterparts. That is PJUs' managements are consistently found to be more accountable and efficient.

In 1989, the MoHE licensed both Amman Private University and the Applied Science University. In less than two decades, a large number of PJUs has been established, graduating students into society. Two new private universities have recently been licensed by the MoHE, but these have not yet started teaching.

\section{Private Universities Ownership and Governance}

Private universities are all owned and organised by non-governmental bodies (families, private institutions, or the public). One private university is owned by a community organisation, while all other private universities are owned by families and public shareholders. There are five private universities publicly listed on the Amman Stock 
Exchange. The private universities must all be registered as commercial companies, and the owners should create a board called the board of managers or directors. Thus, all private universities must implement the commercial companies' law and in the same time they must achieve the accreditation of the private universities law.

The commercial company which owns a private university, and is represented by the board of directors, is in charge of funding the university's buildings. This board is comprised of those who own the highest percentage of the university's shares. Each PJU must have a full time president recommended by the university board of trustees and appointed by the HE council for four years. The president must be Jordanian, a professor, and he or she must not be an owner of the university. The president is in charge of all university activities. Each PJU must have a board of rustees appointed by the MoHE for four years. This board includes the university president, three members chosen by the MoHE, and five members (at most) who own university shares. The other board members are chosen by the university owners, and half of these must be academic professors. In every university, the trustees' board has authority to plan the strategic policies for the university, to approve presidential decisions for organising university activities, and to decide the numbers of students in each faculty and department (on a term by term basis). Moreover, the board's tasks include deciding tuition fees, searching for other financial resources for the university, and determining the salary system for all university staff, including academics and the president (Note 8). Each university must create a university board headed by the president. The university board consists of the vice president, deans, and an academic from each faculty, two administrative managers, two persons from the local community, one current student, and one previous student. One of the tasks of this board is to discuss the university budget (Mah'd et al., 2011). A dean's board must exist in each PJU to discuss all academic issues, such as establishing new programmes, appointing academics, assessing academics' work and nominating academics for scholarships.

By law, a private university's president, vice president, deans, and heads of departments are appointed for a specific time period, which can be renewed. The table below shows the position, rank, period, and nominated party for university management.

\section{Insert Table 1 Here}

The private universities law organises the university budget and financial resources (Note 9). Each university has an independent budget prepared by the president and approved by the board of directors and the trustees' board. The university resources consist of:

\section{Tuition Fees.}

2. Investments returns on buildings and other activities.

3. Grants and endowments (non-Jordanian grants or donations must be approved by the Prime Minister).

4. Income of research projects, production projects, and university utilities.

Each university must open a private account independent of the company's account in any bank in Jordan. The university deposits all university revenue into this account, and withdrawals must be by the president's decision. Every university must allocate 5\% from the annual operational budget for scientific research, including scholarships, training, research publishing, and conferences. The universities must have organised accounts, and they must record entries for all activities according to accounting basics. All accounts and reports have to be audited by an external certified public accountant who should be appointed by the board of directors. The university must create an internal auditing unit, which is responsible to the president. The tasks for this unit include supervision of the budget operation and provision of periodical reports to the president concerning all university financial affairs.

\section{Private Universities Management and Trends}

Although, by law the board of trustees is in charge of all university activities to the MoHE, most strategic and important issues are managed and controlled by the board of directors. In private universities, the board of directors is the business engine which controls all financial and management issues, and sometimes academic issues. In other words, decision-making and university management are under the control of the general manager. Therefore, the interest of the university's owners is the most important objective that directs the university's actions and this can be summarised in the profit motive.

A common trend amongst the PJUs is that they tend to concentrate on low cost programmes, which are perceived as marketable and in high demand in the Jordanian market, for example Business and Computer Science programmes. These programmes are more profitable than other programmes, and their budget is more accepted readily than other programmes' budgets. In the 2008/2009 academic year, the percentage of students who studied in private universities' business schools was about a third of the total students, while in public universities less than $17 \%$ of the total student population studied business. The salary of academics differs between departments within a private 
university, depending on the type of programme. However, this is not the case in public universities. This is another indication that PJUs tend to meet budget requirements in the departments that generate more revenue.

\section{Private Universities and the Budget}

In the business side, as in the academic side, PJUs are successful companies without budget deficits. They have achieved profit every year and are experiencing a rapid increase in student numbers (Note 10). On the other hand, public universities are still struggling with budget deficits; hence, they have decided to increase tuition fees and adopt fund raising programmes, such as the parallel system (Note 11). As stated earlier, the MoHE figures show that private universities spend more than their public counterparts in terms of costs per student. Therefore, the budget practices and treatments in private universities would seem to sustain the effective use of university resources, which helps in maintaining a good position for private universities.

It was previously explained that private universities' income is limited and depends mainly on student tuition fees. In the environment of PJUs, where there is high competition between universities to attract students, controlling expenses is a vital issue. In public universities, the government is responsible for covering the annual budget deficit, while in private universities no government support is available. Therefore, controlling university expenses is one of the important issues which makes effective allocation of resources a central issue of interest in the PJUs. This encourages universities' managements to give more attention to their budgets. Therefore, PJUs make better use of their budgets than public universities do; hence, the budget directly benefits private universities more than it does public ones.

The budget is very important for management in that it is related to all aspects of management accounting (Covaleski et al., 2003). According to several authors, it is a very significant tool in strategic decision-making, performance evaluation, attributing responsibility, subordinate participation, and idea creation.

The government (represented by the MoHE) is interested in comparing the performance of private universities and in protecting the overall quality of university services. By law, all private universities are required to spend $5 \%$ of their operational expenses on scientific research and development, while public universities do not have this requirement. One of the main concerns of the MoHE regarding private universities' budgets is this percentage. Moreover, through private universities' budgets, the government can oversee university accounts, match them with the financial reports, and establish relevant figures and statistics about the Jordanian education system.

Although PJUs are educational institutions, they are also commercial companies seeking profit and competing in a complex sector (Note 12). While by law they are autonomous and independent, they must nevertheless follow MoHE rules and comply with the MoHE requirements. A budget format, which is prepared by the MoHE and discussed with the financial managers in private universities, is applied in each private university. This research examines the budget process, level of participation, compliance with the MoHE budget format, and views of the key people involved with budget. It aims to enrich the management accounting literature and to shed light on a different experience by studying for profit universities in a developing country.

\section{Higher Education Global Overview}

HEIs exist to discover, generate, and develop knowledge, to transfer this knowledge to society, and to provide for the workforce needs of different professions and trades (Buckland, 2009). Increasing global competition in the HE sector has influenced the way it has developed (Altbach, 1998). Governments around the world (especially in developing countries) have also faced major challenges in reforming the financing of HEIs because of rising enrolments in HE and limited resources in public budgets (Johnstone, 1998).

\section{The Role of Higher Education}

Related literature finds university level education to be an important driver for economic growth (see DePillis \& DePillis, 2001; Johnstone, 1998). DePillis \& DePillis (2001) point out three main advantages of HE:

1. Enlarging the supply of skilled and knowledgeable human capital

2. Encouraging specific skills, technical knowledge, and work habits

\section{Promoting economic activities}

$\mathrm{HE}$ is an essential driver for economies and national growth (Al-Lamki, 2002). It aims to provide highly skilled graduates and offer training, research, and development. It is very important to culture and establishes the grounds for creating and producing leaders. HE plays a significant role in preparing and qualifying technical and highly skilled workforce. HE meets the requirements of the national economy and the labour market by focusing on the development of human resources. HE graduates are technologically astute, and prepared for lifelong learning. 


\section{HE Expansion}

"Higher education has moved from the sphere of the national to the spheres of the regional, the international and the global" (Nokkala, 2007, p. 9).

HE, also called tertiary education, is becoming increasingly international. It plays an important role in our lives and has been a vital priority in the public agenda (Al-Lamki, 2002; Altbach, 1998; Johnstone, 1998). In 2008, the World Bank reported that leading world economies expanded the HE sector to enhance the level of education within societies (see Hindi, 2008). This could be one of the reasons why in recent decades, expansion has been noted in HE all over the world. Johnstone (1998) points out the reasons behind HE expansion and diversity:

The growth and expansion of secondary education

The market demand for skilled labour

The growth and demand of the modern world

The increase in student numbers

The increase in educational costs per student

Increasing globalisation has a great effect on employing new learning technologies in the HE sector, as well as in worldwide competition within the HE sector. In order to meet these challenges, the HE system is undergoing fundamental changes towards further autonomy of each institution and more organisation in the structure of HEIs. Despite HE being very important for developing, little systematic research has been done on HE in developing countries (Altbach, 1998).

Until recently, many European countries educated only a small portion of the relevant age group in universities, but in recent years university expansion has been rapid, and these institutions are struggling to meet high demand. Now, the participation rate is growing, placing great pressure on academic institutions. On the other side of the Atlantic Ocean, the United States educates close to half of its college-age population.

Across the globe HE systems have been moving towards universal access, and this is especially noticeable in North America, as well as in a number of East Asian and Latin American countries (Altbach, 1998; Al-Lamki, 2002). Universities have grown in size, with the student numbers obviously increasing, and some universities' annual budgets are now in hundreds of millions of dollars. This expansion has immediate effects, as this increases the responsibility for managers of these larger institutions. Vossensteyn (2004) states that expanding HE requires more efficient use of limited existing resources.

\section{International Higher Education Funding and Management Reforms: An Overview}

In recent decades universities around the world have faced financial problems (Levy, 1999). Universities have experienced rising enrolments while simultaneously experiencing declining budgets, heightened competition in attracting students; this increases demands for accountability (see Vossensteyn, 2004). These and other obstacles require university management not only to track and dramatically improve their institution's performance, but such obstacles also cause academic administrators to make proper decisions at relevant times. Several researchers emphasize that these obstacles place some pressure on governments to change HE funding strategies towards market solutions, such as privatisation and deregulation (Altbach \& Peterson, 1999; Levy, 1999; and Al-Lamki, 2002). A number of reforms since 1990 have tackled the financial and management problems in HE and addressed the shrinking of government funding by encouraging movement towards market orientation or privatisation. Previous studies state that the reform agenda of HE in the 1990s and the new millennium are about market orientation rather than public ownership (Al-Lamki, 2002; Levy, 1999).

Although, HE systems worldwide are diverse and varied in their modes of resource funding and management, universities still share some aims and values, and they face similar obstacles and challenges (Johnstone, 1998). Buckland (2009) states that numerous classic organisational issues arise which affect governance structure in universities. Although, HE is an expensive undertaking, HE became a success business for private universities operating in many countries. These private institutions seek to provide quality education whilst simultaneously achieving profit. Some arguments arise not only concerning how to sustain funding for existing HEIs and to provide funding for expanding systems of HE, but (recently) concerning the need for consumers to share the cost of HE (Al-Lamki, 2002).

There is consistency in the development of the financing and management of worldwide universities and other institutions of HE. There are similar outlines according to financing and management of universities in countries which have dissimilar political-economic systems and technology development (Johnstone, 1998). Financing reforms all over the world are involved in creating new resources and reducing undesirable expenses; this 
encourages governments to move towards private education and to redistribute the public cost of HE to institutions and students. A shortage in university resources has stimulated governments worldwide to change financial strategies and to undertake new financial reforms (Moll, 2003; Vossensteyn, 2004).

A diversity of funding sources is becoming increasingly important in various countries. An appropriate level of HE at an affordable cost without heavy increase in general taxation is an accepted approach in most countries around the world (Johnstone, 1998). It is clear that, when government funding shrinks, diverse sources of funding will be more and more important. Previous research finds that any consensus reached within the diverse range of world colleges and universities could provide guidance for other HE systems facing similar accounting questions (Johnstone, 1998).

In European countries, HE has experienced major financial problems (Shattock, 2000). These problems have encouraged governments to seek out solutions through market innovations, including privatisation (Altbach \& Peterson, 1999). Over the past few decades, methods of financing and management of HE in Europe have been strongly characterised by declining public funding, as well as by an increase of private HE sources (see Nokkala, 2007).

The United Kingdom seems to be leading the change in Western Europe. Students are charged for tuition, with loans made available to low-income families. Scotland is an example of British education wherein $56 \%$ of total university funding now comes from the public compared to 83\% in 1982 (Scotland Universities, 2005). The method of funding HE being tried in Australia and several other countries includes a "graduate tax" on university graduates, based on their incomes in the years following graduation, to provide further payment for HE (Altbach \& Knight, 2007).

Germany, whose rapidly growing HE system is facing severe fiscal constraints, is also beginning to consider alternative methods of funding HE. There is an agreement that standards have fallen in Germany's HE system, and that an infusion of funding is necessary to improve conditions. In all of these cases, the student will pay more for the privilege of studying.

Since 1990, Private HE sector in Poland has been witnessing a rapid growth comparing with public HE (Duczmal, 2006). Duczmal (2006) states that when there is a market failure in HE, government intervention in this sector is considered to be justified. He explains that there are different reasons set behind the market failure such as when the educational performance is below the acceptable norms. In Poland the government intervenes by distributing subsidies or by regulating laws. Therefore, the government applies new policies to remedy market failure and to enhance educational performance.

In Australia, the government has issued new policies for the HE sector with the intention of improving the financing and management of universities (Moll, 2003). This reform is called the "Dawkins Review." These policies are subject to market mechanisms and greater competition through the reduction of government funding, which induces universities to diversify their financial resources, increases accessibility to HE, and requires payment of tuition fees. Although most Australian universities are public and state-owned, (Note 13) they are becoming more corporate, adopting private sector models and enhancing their accountability. Moll (2003) outlines how financial management reform in Australia includes the following objectives: to develop budgetary and regulatory processes, to support new techniques and systems that focus on results, and to change administrative procedures to help in the research decision. The institutional framework in HEIs includes regulations, standards, and traditions that will affect universities' policies. Government funding mechanisms, resources allocation, educational standards, and regulations have an impact on HE autonomy and methods of management.

In countries dominated by the public sector, such as most African countries, the state pays most of the bills, but increasingly the cost of supporting universities far outpaces the capability of governments which are facing dire economic difficulties. In countries where most students attend private HEIs, some in Asia and a few in Latin America, students and their families pay most of the costs of $\mathrm{HE}$.

Decentralisation, the movement towards greater autonomy and accountability, has been the main theme over the past two decades in Latin America, where several governments have been contemplating how to balance institutional autonomy with accountability (Schwartzman, 2002). Several researchers draw attention to a dynamic change in the governance and management of HE in Latin America, consequent on the manifest growth in this sector and the diversity of the private sector which solidifies their position as alternative to public HE (Levy, 1999). According to Schwartzman (2002), in the past, the MoE determined budget allocations, student admission policies, and the content of curricula in public HE in many Latin American countries, while individual universities had little influence on the number of staff and positions, the level of salaries, and promotions. This approach has noticeably changed in recent years, as universities increasingly became accountable for external funding and have greater freedom and autonomy, so that they can be held responsible for their success and failure. 
In Venezuela, greater freedom for universities in regard to budget, governing, personnel policy, and academic programmes has been guaranteed by the constitution (World Bank, 1999). This stands as evidence of the growth in private provision of tertiary education and the policy of cost-recovery in Latin America. Altbach \& Peterson (1999) explain how the expansion of student numbers in HE in Chile from 250,000 in 1990 to 500,000 in 2003 was mainly financed by private sources.

The trend of decentralization in Latin America extends from the university-government relationship to individual departments. Top-down university management, where all decisions regarding external contracts and funding allocations require approval from the rector, is too cumbersome within the new academic environment. In an increasing number of universities across Latin America, external contracts and decisions about funding allocations can now be managed at a lower level.

East Asian countries have experienced a marked tendency towards market orientation and have witnessed a high rate of private HE. Lee (1998) explains that in South Korea private institutions contribute more than three quarters of all students, with tuition fees accounting for an average of $63.2 \%$ of the overall financial resources of these institutions. This reform was not the solution for bankruptcy problems; indeed, several educational institutions went bankrupt. The South Korean government gave private institutions financial support for the first time in 1990, and in 1997 this was raised (for some universities) to as much as $76 \%$ of their entire education budget (Lee, 1998). Another educational reform planned to combine South Korean educational institutions into a larger institution with government financial support (Lee, 1998). This includes some norms and standards regarding to management, structure, and governance.

In the Middle East, particularly in Oman, HE is a recent phenomenon, having begun in 1970. Al-Lamki (2002) states that Oman's government has subsidy schemes to promote the development of the private HE sector. At present, there are ten private colleges in this country.

Slow economies and high rates of unemployment have restricted the money available for HE (especially in developing countries), with the result being that academic institutions have had to expand enrolments without adequate financial resources (Altbach, 2003). This is particularly the case in developing countries, especially in Latin America, East Asia, and the Middle East, where private HE is undergoing a major change. In European countries, however, where universities were not been permitted to charge tuition and there was no tradition of private philanthropy to HE, this is still in the beginning stages, and changes have only begun in recent years.

\section{Private Higher Education}

The privatisation of $\mathrm{HE}$ is by all accounts a global phenomenon.

(Quddus \& Rashid, 2000. p 487) Privatisation in this research refers to the shifting of ownership from the public to the private sector or establishing new private projects rather than public ones. Although privatisation of HE is still a new phenomenon in some countries, it is one of the main movements in HE worldwide and has played an important role in the provision of HE (Johnstone, 1998; Altbach \& Knight, 2007). Privatisation fills the gap when the state is unwilling or unable to provide the essential support for an expanding HE sector, or when public institutions of HE lack the capacity to satisfy the fast growing demand for HE. Private enrolment in HE is growing rapidly almost all over the world, especially in the U.S.A and developing nations, such as countries in East Asia, the Middle East, Latin America, the former Soviet Republic, and Eastern Europe (Altbach \& Knight, 2007).

Where accountability is high, private organisations are able to pursue the profit objective (and indeed most objectives) better than state agencies can (Terbilcock \& Iacobucci, 2003). In support to this view, Nechyba, (2005) states that private schools have greater resource efficiency and are more effective in translating money into outcomes. Therefore, the phenomenon in which shifting the burden of the cost of HE from dependence on the government or taxpayers to some reliance on parents and/or students is now accepted and adopted worldwide.

Public HEIs are more reliant upon the governments and public support, while private institutions depend on private financial sources. However, although public HEIs are more broadly based (Altbach, 1998), private institutions are growing more rapidly than public ones are. Private institutions could compete on the same ground with other private institutions and public institutions, while some private institutions aim to distinguish themselves by creating new programmes and serving particular groups (Altbach, 2003).

During recent decades, HE has been regulated in most of the world by the government. Thus, it has been very difficult to escape from tight state regulation and the dominance of public ownership. Since the late 1970s, increasing demand on the role of the private HE sector has been remarkable, and many countries support the idea of decreasing the HE fund. In today's world, privatisation in education has become a major international trend (see 
Sanyal, 1998; Altbach, 1998; Quddus \& Rashid, 2000; and Altbach \& Knight, 2007). The private sector now plays a key role in financing HE. This can be distinguished in four forms:

1. The privatisation of public institutions (such as in Latin America)

The public institution has become more market-oriented, moving away from governmental aid towards student fees, sale of research, contracts, and entrepreneurial training.

2. Private institution with state support (as in India)

The government's share in overall education expenditure has been declining steadily, and, therefore, HEIs are becoming more autonomous and independent.

3. The establishment of self-financed private institutions, sometimes charities (as in the U.S.A)

Institutions are established and owned by non-public organisations and financed by tuition fees rather from the state budget.

\section{Establishing for-profit private institutions (as in the Middle East)}

In this form, private HEIs may be regulated by the government and the educational ministry but they are financed and managed by investors, as in the case of Jordan. Conversely, they may be regulated by companies' law and financed and managed by investors. In both methods government do not pay anything. Rather, the government often takes taxes, and sometimes accreditation fees from these institutions.

The largest number of private institutions exist in Asia ( $60 \%$ of $\mathrm{HE}$ in Indonesia is provided by the private sector), followed by the U.S.A The private sector is growing rapidly in Latin America, Arabian countries, and Eastern Europe. The private sector market is smaller in Western Europe and Africa, but it is on the increase in both of these regions.

Numerous methods for attaining universities funding exist in the world. Research and development is encouraged in a majority of countries. Public and private universities carry out both teaching and research in the U.S.A Although about $80 \%$ of students study in public HEIs, paying tuition sums of only about a third of the actual cost of instruction (with state funds and other resources covering the rest), $20 \%$ of students study in private institutions, where they pay the bulk of the educational costs (Kent, 2006). Sources of HE funding are diverse and differ between countries. Competition at the tertiary level is high in the U.S.A university system, which involves a large number of varied institutions. There both public and private institutions provide HE services. The rising competition in research funding has increased the demand for universities to properly manage their costs (Kent, 2006). Kent (2006) also argues that competition has enabled the U.S.A to create unparalleled excellence in its graduate programmes.

All of these changes will have dramatic implications for HE worldwide. In Europe, where public funding has traditionally been the norm, and the state pays most educational costs, academic systems are becoming more differentiated by quality and prestige (Altbach, 2003; Altbach \& Knight, 2007). However, for many governments, facing budget cuts, debates about private/public education have started to introduce tuition fees, although these are at moderate levels. Many European countries fit this pattern, while private institutions still play an insignificant role in the statistics of the HE system (Nokkala, 2007, Duczmal, 2006). European universities are involved in basic research, and they are responsible for much of the scientific progress of the past century. Altbach \& Knight (2007) conclude that research is expensive, and it is still unclear how academic research will be funded in the future without the buyers (students). Since 1990, the number of private HEIs has grown rapidly, especially in Eastern Europe, while the private HE sector in Western Europe is still in its infancy. However, some reforms have been introduced with the intention of reducing the financial burden on the government, while other reforms aim to achieve the need of increasing the proportion of students among the general populace.

In the huge bulk of Western Europe, little or no tuition fees are paid by students, but they are responsible for their own living costs. Recently, heated debates have occurred in most European countries over whether that public universities should charge tuition, and this change is the result of a combination of demographic pressures, fiscal realities, and reinvigorated conservative ideas about public spending in Europe (Johnstone, 1998). However, British universities are all public, and they now charge students tuition fees in a move which signals the beginning of a major change throughout Europe. In Germany, where the private HE sector does not play a large role in the educational system, the total number of students at private HEIs increased from about 11,000 in 1992 to more than 40,000 in 2006. The only significant exception in Western Europe is Portugal, (Note 14) where the private HE sector has developed during the last two decades and strong political support has been given to the increasing role of private universities. Since the 1990s, most universities have had more freedom, and autonomy, and there has been a marked increase in the decentralisation of the responsibilities and emergence of private HE sector (Kuoppala, 2005). 
Additionally, it is remarkable in Europe that universities' management systems drew their inspiration from systems developed for the private sector, in particular from management by objectives and results-based management models (Kuoppala, 2005). Kuoppala (2005) finds that the strategy of result-based management has supported other trends in universities; thus, positive quantitative improvements have been made.

In Eastern Europe, as in Western Europe most of the HE sector used to be public; however, questions regarding significant demand for private universities have arisen in the last two decades. Since 1989, the countries of Eastern Europe have experienced an extraordinary growth and change of their HE systems, where the percentage of students in private HE has jumped from zero to more than $30 \%$ in less than fifteen years. Teixeira \& Amaral (2001) use Romania as an example of a nation in which there has been a huge growth in private HE. According to government figures, the number of students who study in private institutes has doubled about 15 times from 1990 to 2005, while the numbers at public universities has risen by only about four times. Poland is one of the most educated countries in Eastern or central Europe; here the net ratio of accessibility to HE was 10\% in 1990 and 38\% in 2006 with around two million enrolments in HE. Before 1990, there was no significant appearance of private HE in Poland, while now around half of the HE sector is private.

Private universities have long been a central part of HE provision in the eastern part of Asia; they enroll the majority of students, in some cases upwards of $80 \%$ (Altbach \& Knight, 2007). In India, to a great extent, private colleges are subsidised by government funding and the large majority of students attend private colleges. The private sector is also a growing force in parts of Asia where it has thus far not been active, such as in China, Vietnam, and the central Asian republics.

In many East Asian countries (such as Japan, Korea, Taiwan, and the Philippines), most students attend private universities and colleges, and they pay for the full cost of their education. Tuition is also charged in the small and relatively elite public HE sector. For instance, as is the case with several other countries, South Korea has both private and public universities. Korean private HEIs, which have made a considerable contribution to the economic, social, and cultural development of the nation, have depended typically on student tuition fees (Lee, 1998). Although, the government claims that private universities are independent; in fact no private HEI in Korea can avoid or ignore government suggestions. This is simply a means of protecting themselves from any potential unfair behaviour from government (Lee, 1998). The very same situation is noticeable in Jordan. In contrast, China once provided free HE, but it has also moved to tuition-based arrangements. Some poor countries in Asia provide totally free HE.

In North African countries, universities are state-owned. In 1996, there was no significant private HE in Egypt, while private $\mathrm{HE}$ is noticeably increasing at present. By law, Egyptian students in public universities should not worry about the tuition fees: in Egypt, public universities get their funding from the state. Egyptian Private Universities were established under a new law in 1993 but only started in 1996, having a small student body and high tuition fees compared to public HEIs. These universities do not receive any state funding, they are dependent on their supporting bodies, private organisation and societies.

Public universities in Syria, one of the Middle East and Arab countries, provide HE and free room for less than \$20 per year, which is a very insignificant cost. The government spends a large amount of money on supporting HE, and universities still struggle to facilitate the demands for huge number of enrolments every year. The main universities, which are all public, accept more than their capacity every year. Since 2001, the Syrian government has allowed investors to open private universities. This movement is considered a promising step in the journey of Syrian HE. According to official figures, in 2009 there are eight private universities. Despite these successes in undergraduate learning, government funding for education has actually been reduced: it now accounts for only $\$ 50$ million out of Syria's annual budget of $\$ 11$ billion, while funding for academic research account for only $\$ 3.8$ million.

Palestinian universities, which suffer because of the situation in the West Bank and Gaza, have their own administrative organisation. They have traditionally depended financially on student tuition fees and international subsidies, but subsidies ceased after 2000. The MoHE in Palestine controls and coordinates the activities of the institutions of HE within the framework of national policies.

\section{Summary}

Jordan, Jordanian HE, and HE worldwide have been discussed in this paper in order to draw attention to the importance of this study. This paper presents and underlines why the Jordanian experience is of special interest, and why it is worth examining in some detail. The Jordanian HE system is a unique one, which includes private and public sectors, and has grown increasingly in recent years. While, HE worldwide differs in terms of financing and managing of universities, there is a consistent movement towards minimising state funding for universities and 
increasing students' participation in the cost of their education. The following are some points summarising the importance of this paper:

1. Jordan, despite its small size, is one of the most developed Middle East countries, in which the majority of the population is interested in education (Mah'd, 2010). This accounts for the fact that universities in Jordan have enlarged rapidly during the last decades.

2. The Jordanian economy is very open, fostering international transactions of considerable importance which lead to significant external investments. These reflect on Jordan's geographical position, market size, and economic structure. The education laws are modern, with major universities being privately owned. Foreign investments are permitted to operate. There is much competition in the service sector, including within private HE.

3. Worldwide, there is a trend towards private HE. Private universities are mainly financed by student tuition fees, and sometimes they do not receive any subsidies from the government. A proper budget system might facilitate the need for effective managing of university resources and sound decision-making.

4. Little has been written about finance and management of private HE in Jordan, despite two decades of experience with private HE.

\section{References}

Aladwan, Y., \& Qutaishat, M. (2007). Financing options for public universities in Jordan: current status and future horizons. Working Paper, MoHESR.

Al-lamki, S. M. (2002). Higher education in the sultanate of Oman: the challenge of access, equity and privatisation. Journal of Higher Education Policy and Management, 24(1), 75-86. http://dx.doi.org/10.1080/13600800220130770

Alshurfat, S. S. (2003). The Role of Primary School Teachers in Education Change in Jordan. (Unpublished PhD Thesis). Sydney, University of Western Sydney.

Altbach, P. G. (1998). Comparative Higher Education. Norwood, NJ: Ablex.

Altbach, P. G. (2003). Introduction to higher education theme issue on the academic profession in central and eastern Europe. Higher Education, 45(4), 369-389. http://dx.doi.org/10.1023/A:1023949808905

Altbach, P. G., \& Knight, J. (2007). The internationalization of higher education: motivations and realities. Journal of Studies in International Education, 11(3-4), 290-305. http://dx.doi.org/10.1177/1028315307303542

Altbach, P. G., \& Peterson, P. (1999). Higher Education in the 21st Century: Global Challenge and National Response. Boston, Institute of International Education and Boston College Centre for International Higher Education.

Bruns, W. J., \& Waterhouse, J. H. (1975). Budgetary control and organisation structure. Journal of Accounting Research, 13(2), 177-203. http://dx.doi.org/10.2307/2490360

Buckland, R. (2009). Private and public sector models for strategies in universities. British Journal of Management, 20(4), 524-536. http://dx.doi.org/10.1111/j.1467-8551.2008.00593.x

Burke, D. L., \& Al-Waked, A. A. (1997). On the threshold: Private universities in Jordan. International Higher Education, (9 (Fall)).

Covaleski, M., Evans, I., John, H., Luft, J., \& Shields, M. D. (2003). Budgeting research: three theoretical perspectives and criteria for selective integration. Journal of Management Accounting Research, 15, 3-49. http://dx.doi.org/10.2308/jmar.2003.15.1.3

Department of statistics. (1987). Higher Education Statistics. Amman, Jordan, Department of Statistics.

DePillis, E. G., \& DePillis, L. G. (2001). The long-term impact of university budget cuts: A mathematical model. Mathematical and Computer Modelling, 33, 851-876. http://dx.doi.org/10.1016/S0895-7177(00)00285-5

Duczmal, W. (2006). The Rise of Private Higher Education in Poland: Policies, Markets, and Strategies. Enschede: Postbus.

Hindi, L. (2008). Hashemite Kingdom of Jordan Leads MENA in Education Reform. Jordan Times. Amman, Jordan, World Bank.

Hutaibat, K. (2005). Management Accounting Practices in Jordan - A Contingency Approach. Accounting and Finance, School of Economics, Finance and Management. (Unpublished PhD Thesis). Bristol, Bristol University.

Issa, S. S. (2000). Quality assurance of engineering education in private universities in Jordan. International Journal of Higher Education, 6, 119-128. 
Jansen, W. (2006). Gender and the expansion of university education in Jordan. Gender and Education, 18(5), 473-490. http://dx.doi.org/10.1080/09540250600881600

Johnstone, B. (1998). The Finance and Management of Higher Education: A Status Report on Worldwide Reforms. New York, State University of New York.

Kent, H. (2006). Universities in the U.S. National Innovation System. Arizona, Arizona State University.

Kharman, N. (2005). Educational Developments in Jordan: a Comparison of Private and Public Schools. (Unpublished PhD Thesis). Reading, University of Reading.

Khasawneh, F., Bataineh, S., Nazer, M., Abu Qudais, M., \& Al-Akhal, R. (2008). Higher Education at a Glance in Jordan. Al-Manar.

Kuoppala, K. (2005). Management by results at Finnish universities. Journal of Higher Education Policy and Management, 27(3), 345-355. http://dx.doi.org/10.1080/13600800500283692

Lee, S. (1998). Korean private higher education faces economic crisis. International Higher Education, 19-20.

Levy, D. C. (1999). Reform: Latin America in the 1990s. International Higher Education, 15, 10-11.

Mah'd, O. (2010). The budgetary process in Private Jordanian Universities (PJUs) and the role of budget participation. (Unpublished PhD Thesis). School of Accounting and Finance. Aberdeen, University of Aberdeen.

Mah'd, O., \& Buckland, R. (2009). The budget process in Jordanian Private Universities (JPUs). Accounting in Emerging Economies, 9, 193-228.

Mah'd, O., Nassar, M., Nimer, K., \& Al-okdeh, S. (2011). The Impact of Managers' Related Variables and Department Features on Budget Characteristics: The Case of Private Jordanian Universities. International Business Research, 4(4), 199-210.

Ministry of Education. (2008). Inclusive Education: The Way of the Future. The 48th Session of Education. Geneva.

Ministry of Higher Education and Scientific Research. (2005). Towards a National Strategy for Higher Education and Scientific Research for 2005-2010. Amman-Jordan, The Ministry of Higher Education.

Ministry of Higher Education. (2001). The Temporary Law of Private Universities 43. Ministry of Higher Education, Amman, Jordan.

Ministry of Higher Education. (2009). The Law of Jordanian Universities 20. Jordanian Government, Ministry of Higher Education.

Moll, J. (2003). Organisational Change and Accounting Control Systems at an Australian University; A Longitudinal Case Study. (Unpublished PhD Thesis). School of Accounting and Finance, Griffith, Griffith University.

Nechyba, T. (2005). Mobilizing the Private Sector: A Theoretical Overview. Kennedy School of Government. Duke University and NBER, Harvard University.

Nokkala, T. (2007). The Bologna Process and the Role of Higher Education: Discursive Construction of the European Higher Education Area. In Enders, Jürgen \& Jongbloed, Ben (Eds.), Public-Private Dynamics in Higher Education. Expectations, Developments and Outcomes (pp. 197-219). Bielefeld: Die Deutsche Bibliothek.

Quddus, M., \& Rashid, S. (2000). The worldwide movement in private universities. American Journal of Economic and Sociology, 59(3), 121-129. http://dx.doi.org/10.1111/1536-7150.00039

Sanyal, B. C. (1998). Diversification of Sources and the Role of Privatization in Financing Higher Education in the Arab States Region. Paris, International Institute for Educational Planning.

Sanyal, B. C. (2006). Financing Higher Education: International Perspectives. pp (19-21) of Higher Education in the World: the Financing of Universities. Barcelona, GUNI: 19-21.

Saunders, M., Lewis, P., \& Thronhill, A. (2009). Research Methods for Business Students (5th ed.). Edinburgh: Pearson Education limited.

Schwartzman, S. (2002). Higher education and the demands of the new economy in Latin America. Background paper for the 2003 LAC Flagship Report. Washington, DC, World Bank.

Shattock, M. (2000). Strategic management in European universities in an age of increasing institutional self reliance. Tertiary Education and Management, 6(2), 93-107. http://dx.doi.org/10.1080/13583883.2000.9967015 
Teixeira, P., \& Amaral, A. (2001). Private higher education and diversity: an exploratory survey. Higher Education Quarterly, 55(4), 359-395. http://dx.doi.org/10.1111/1468-2273.00194

Trebilcock, M. J., \& Iacobucci, E. M. (2003). Privatization and accountability. Harvard Law Review, 116(5), 1422-1453. http://dx.doi.org/10.2307/1342731

Vossensteyn, H. (2004). Fiscal Stress: Worldwide Trends in Higher Education Finance. ECA Education Conference, Twente, the Netherlands, World Bank.

Wilson, R. (1987). Islamic banking in Jordan. Arab Law Quarterly, 2(3), 207-229. http://dx.doi.org/10.2307/3381694

World Bank. (1996). Jordan Higher Education Development Study. Amman, Jordan, Human Resources Division, Country Department II, Middle East and North Africa Region: No.15105-Jo.

World Bank. (1999). Education in the Middle East and North Africa: A Strategy towards Learning for Development. Washington, World Bank.

Zeitun, R. (2006). Firm Performance and Default Risk for Publicly Listed Companies in Emerging Markets: A Case Study of Jordan. (Unpublished PhD Thesis). School of Economics and Finance, University of Western Sydney, Sydney.

\section{Notes}

Note 1. It was Jordanian Telecommunication (JTC) and became Jordan Telecom Group (Orange).

Note 2. See (Johnston, 1998) for more information.

Note 3. See MoHE and Scientific Research (2005).

Note 4. There are another three newly licensed universities begun in 2009.

Note 5. See www.mohe.edu.jo.

Note 6. Private universities in most parts of the world receive financial support: they are even considered to be charities and receive public funds or tax exemption. None of them pays fees to the government.

Note 7. The percentage of foreign students in private universities is higher than the percentage of foreign students in the public, amounting to half of the total student population in some private universities (Mah'd, 2010).

Note 8. For more information see Private Universities Law No. 43.

Note 9. See Sections 17 and 18 of the Private Universities Law No. 43.

Note 10. See http://www.mohe.gov.jo/Statistics/tabid/69/Default.aspx accessed at Sep 30th 2010.

Note 11. The parallel system students require to pay high tuition fees, like the tuition fees in the private universities, and they are not required to have high grades like the normal students.

Note 12. The universities sector in Jordan is complex that the PJUs should depend on the tuition fees and in the same time compete with public universities which are supported by the government and in the same time provide high educational services to attract students.

Note 13. There is one private university in Australia: Bond University, established in 1989.

Note 14. See Johnstone (1998).

Table 1. Appointment of Jordanian university administrators

\begin{tabular}{lllll}
\hline Position & Rank & Period & Nominated party & Approved by \\
\hline President $^{\text {a }}$ & Professor & 4 years $^{*}$ & Board of trustees & MoHE \\
Vice president & Professor & 2 years $^{*}$ & Board of trustees & MoHE \\
Deans & Professor $^{\text {b }}$ & 2 years $^{* *}$ & President & Trustees board \\
Department head & Professor $^{*}$ & 1 year $^{* *}$ & Dean & Deans' board \\
\hline
\end{tabular}

Note: ${ }^{*}$ Renewable once.

${ }^{a}$ The university president and vice president must be Jordanian, and they can-not own any university shares.

${ }^{\mathrm{b}}$ The dean and the head of the department can be lower ranked if required.

Source: Developed by the authors from Law No. 43 in 2001. 


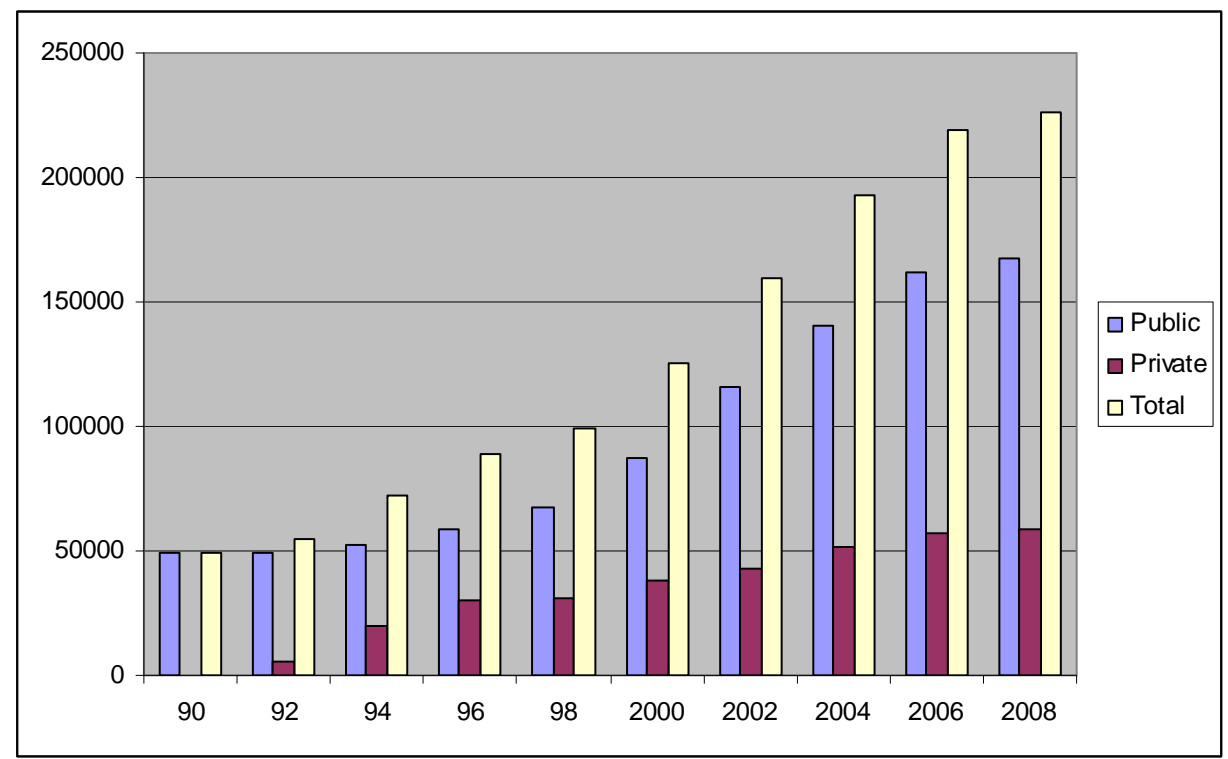

Source: MoHE (2008).

Figure 1. The increasing number of students in Jordanian universities 